\title{
内陸地震発生の直前に地質構造帯に沿って現われる 地震活動の前兆的静穏化
}

\author{
吉 田 明夫* 伊藤 秀 美** 細 野 耕 司**
Precursory Seismic Quiescence Appearing along Tectonic Zone Just before the Occurrence of Intraplate Earthquake

Akio YOSHIDA*, Hidemi ITO** and Kohji HOSONO**

\begin{abstract}
Several examples are presented which seismic quiescence appeared in a wide area around the foci of intraplate earthquakes before their occurrence. A noteworthy feature is that the quiescence area extends along tectonic zones over more than several times of the focal region of the main shock. This phenomenon suggests that stress in a wide area along tectonic zones changes before the occurrence of major intraplate earthquake. We consider that the stress change is a manifestation of a significant physical process leading to earthquake occurrence. An apparently puzzling fact which earthquake precursors are sometimes observed at distant places from the focal region in the specific direction may be explained by such stress change. Further, it is expected that the precursory seismic quiescence provides us with a promising clue to the short-term prediction of intraplate earthquake.
\end{abstract}

Key words : seismic quiescence, intraplate earthquake, tectonic zone, stress change, earthquake prediction

キーワード : 地震活動の静穏化, 内陸地震, テクトニックゾーン, 応力変化, 地震予知

\section{I.はじめに}

1995年兵庫県南部地震の直前に, 震源域から丹 波地域にかけての広い範囲で微小地震活動の静榣 化が見られた。著者の一人はこの静穏化が兵庫県 南部地震の前兆であった可能性があると指摘した （吉田，1995）が, その根拠は，内陸でやや顕著な 地震が発生する前に, その地震の震源域を含む主 要な活断層帯, 地質構造帯などのテクトニックゾー ンに沿って微小地震活動が静穏化する現象がしば
しば観測されることによる。本論文ではそうした 例をいくつか紹介するとともに, この静穏化現象 が有する意義について, 地震の発生メカニズムや 地震予知の観点から若干議論する。

なお, 用いたデー夕は気象庁地震月報震源及び 同速報震源である。

\section{II. 地震発生直前に地質構造帯に沿って 現われた静穏化現象の例}

（a） 1990年新潟県南部の地震 $(M 5.4, M 5.3)$

\footnotetext{
* 気象研究所地震火山研究部

** 気象庁地震火山部

* Seismology and Volcanology Research Department, Meteorological Research Institute

** Seismological and Volcanological Division, Japan Meteorological Agency
} 
新潟市から信濃川沿いに長野, 松本にいたる地 域は活褶曲構造が観察されるなど, 地殻の活構造 帯として古くから注目されてきた（例えば, 大森, 1910 ; 大塚, 1942 ; 藤田, 1983)。浅い地震の分布 はそこから更に南西方向に延び, 飛騨山地を経て 長野県西部地震の震源域に続く。このサイスミッ クゾーン（以下，北信越サイスミックゾーンと呼 称する）では，1891年濃尾地震や1944年東南海地 震, 1964年新潟地震等の直後に地震活動の活発化 が見られた（Yoshida，1987，1989；Mogi，1988） ほか，M2.5以上の地震が $30 \mathrm{~km}$ 以内の範囲で 30 日以内に 3 個以上というようなクラスター的活動 がほぼ同時期に全域で生じるなどの現象もしばし ば観測される（Yoshida et al., 1994）。こうした ことから, 北信越サイスミックゾーンはテクトニッ クな応力が集中しやすく, またその変化が伝わり やすい地殼の弱帯であると考えられる。

この北信越サイスミックゾーン内の新潟県南部 で，1990年12月にM4以上の地震 12 個を含む群発 的活動（M5 以上は 12 月 7 日に 2 個）が発生した。 図 1 はその群発的活動が始まる前約 1 年間におけ る北信越サイスミックゾーンの地震の時空間分布 であり, また, 図 2 は同ゾーン内の地震の $\mathrm{M}-\mathrm{T}$ 四及び積算図である。これらの図から, 群発的活 動の始まる 1 力月ほど前から, 北信越サイスミッ クゾーン内で地震活動が静穏化した様子が明らか に見てとれる。

1992年12月 27 日に新潟県南部の津南町付近で発 生したM4.5の地震の直前にも, 北信越サイスミッ クゾーンに沿って震源域よりもかなり広い領域で 微小地震活動の静穏化が観測されたが，1995年新 潟県北部の地震については, また別の特徵が見ら れた。次にこれについて述べる。

\section{（b） 1995 年新潟県北部の地震 $(M 6.0)$}

北信越サイスミックゾーン北端の新潟県北部で 1995年4月 1 日に $M 6.0$ の地震が発生した（改訂 $M$ 值は 5.5)。震源近傍では1994年10月に群発的活動 が現われ, 新潟市付近の地震空白域（石川, 1990) をはさんでその南側, 1990年12月の新潟県南部の 地震発生域付近でもほぼ同じ頃から活動が活発化 した（気象庁地震予知情報課, 1995a; 東北大学
理学部，1995)。これらの活動は以後断続的に続 き，特に震源近傍では新潟県北部の地震発生直前 に到るまで顕著な活動が見られた。しかし，震源 域付近を除けば，直前の約 1 カ月余りの間, 北信 越サイスミックゾーンの活動はやはり低下してい たように思われる。その様子は，例えば新潟県北 部の地震の前 1 年間における北信越サイスミック ゾーン内の地震の時空間分布（図 3 ) や, 震源域 を除いた領域の地震数の積算（図 4 )に見ること ができる。

新潟県北部の地震の前になぜ北信越サイスミッ クゾーン内で静穏化が明瞭でなかったか, 特に, 震源域でなぜ静穏化が見られなかったのか。著者 らは, その理由の一つに, 新潟県北部の地震の震 源域周辺の活動と, 福島県西部の田島付近の活動 とが関連性を持っていることがあるのではないか と考えている。その関連性はこれら両地域をつな ぐゾーンに発生した地震の時空間分布図（図 5,

図6）から見てとれるが，田口・吉田（1996）は また, 両地域の地震エネルギー放出変化曲線を比 較して実際にかなり大きな相関係数が得られるこ とを示した。なお，この相関性は東北大学理学部 (1995) によっても指摘されている。

さて, 二つの地域間で地震活動に相関が見られ るということは, 一方における応力状態の変化が 他方の応力状態に影響を与えやすいということを 意味する。実際, 1994年12月18日に福島県西部で $M 5.5$ の地震が発生した直後から新潟県北部の地 震の震源域でも活動が活発化した（図 6 参照）。 こうした事実を基に推論するならば，新潟県北部 の地震の震源域周辺が直前に静穏化しなかったの は, その付近では1994年10月頃から福島県西部で の活動による応力変化の擾乱を絶えず受けて，い わば地震発生が誘発されやすい状態が続いていた ためということができるように思われる。

\section{(c) 1993 年飛騨の地震 $(M 5.0)$}

長野, 岐阜, 富山の三県境付近の飛騨山脈直下 で1993年 7 月に群発的活動が発生し，7月19日に M4.7,20日にM5.0の地震が観測された。図 7 は その活動域を北端として, 松本から諏訪湖, 赤石 山脈を経て駿河湾北西部に到る糸魚川-静岡構造 

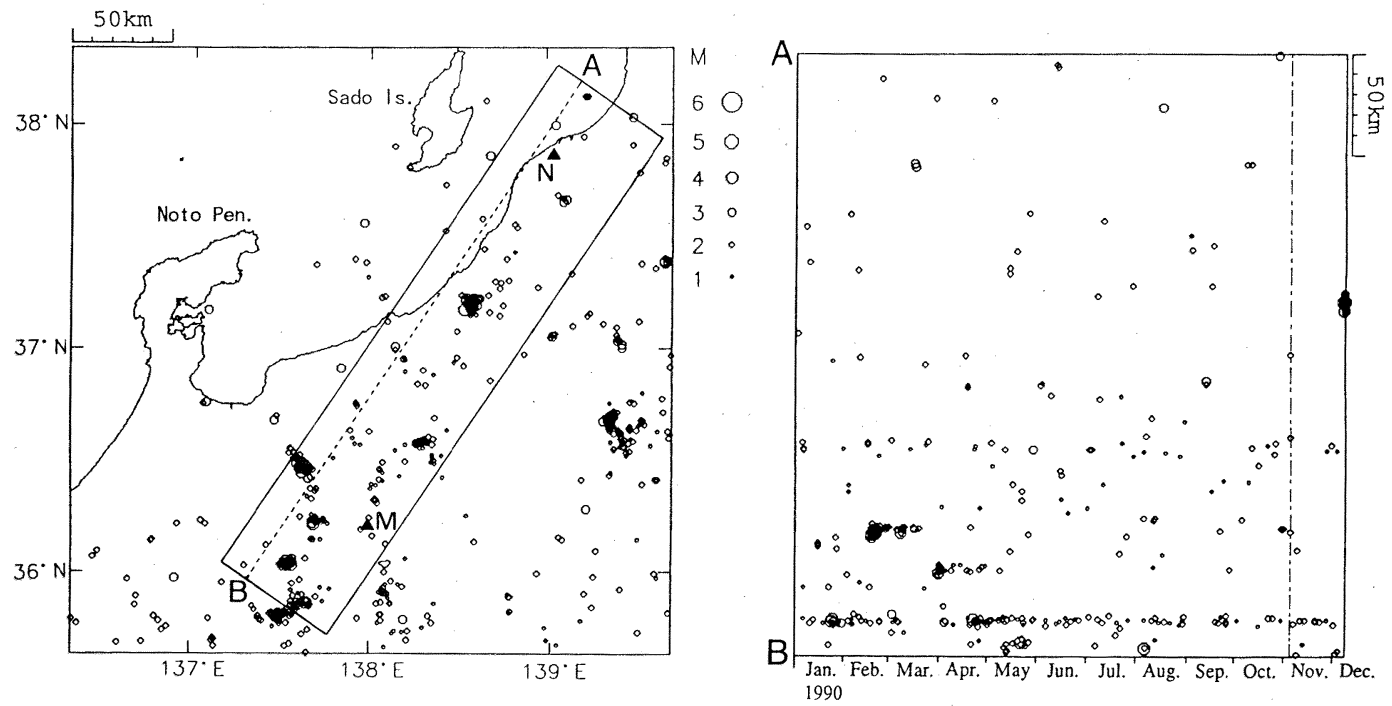

図 1 北信越サイスミックゾーン (左図の矩形領域) に発生した地震 $(M \geqq 1.0$, 深さミ30km) の時空間 分布. 期間は1990. 1.1-1990. 12.7.

$\mathrm{N}$ : 新潟, $\mathrm{M}$ : 松本.

Fig. 1 Space-time disribution of earthquakes with $M \geqq 1.0$, depth $330 \mathrm{~km}$, occurred in the Hokushin-etsu seismic zone in the period Jan. 1, 1990-Dec. 7, 1990.

$\mathrm{N}$ and $\mathrm{M}$ indicate Niigata city and Matsumoto city, respectively.
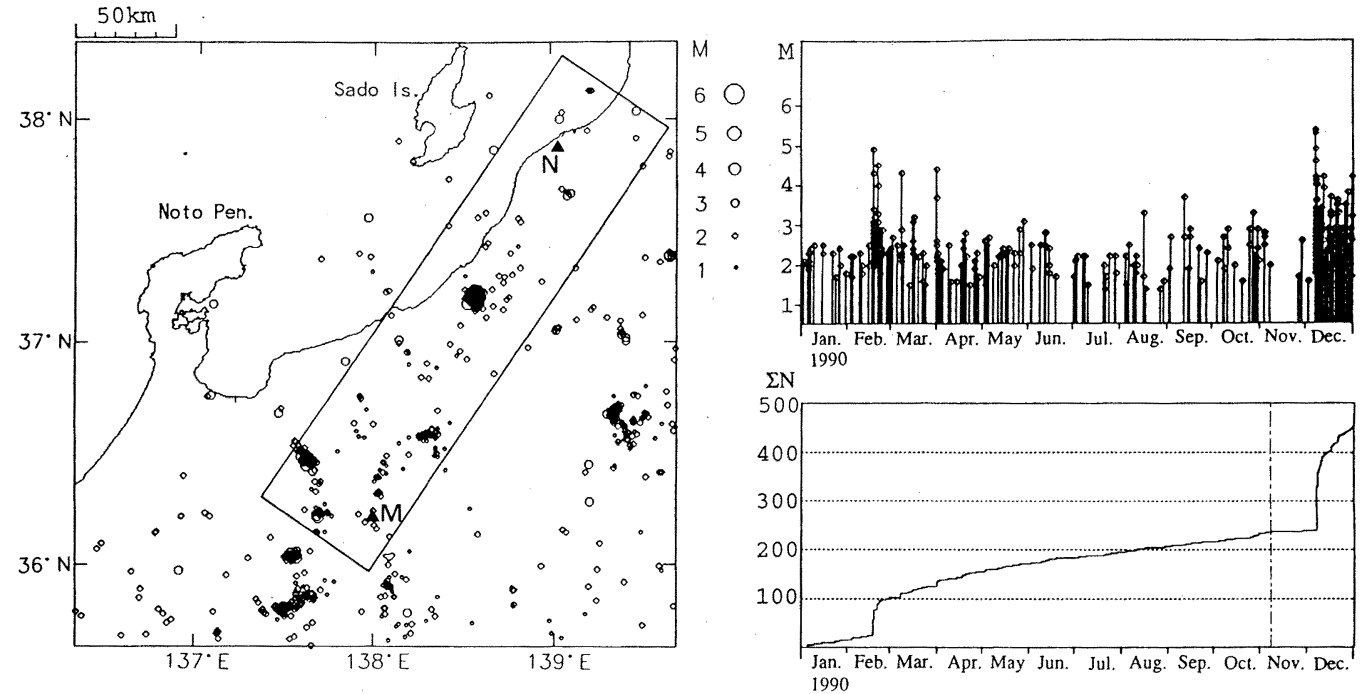

図 2 北信越サイスミックゾーンに発生した地震（ $M \geqq 1.0$, 媣さミ $30 \mathrm{~km})$ の $\mathrm{M}-\mathrm{T}$ 図（右上）と積算 (右下)

$\mathrm{N}$ : 新潟, $\mathrm{M}:$ 松本.

Fig. 2 Magnitude-time diagram and cumulative number of earthquakes in the Hokushinetsu seismic zone.

$\mathrm{N}$ and $\mathrm{M}$ indicate Niigata city and Matsumoto city, respectively. 

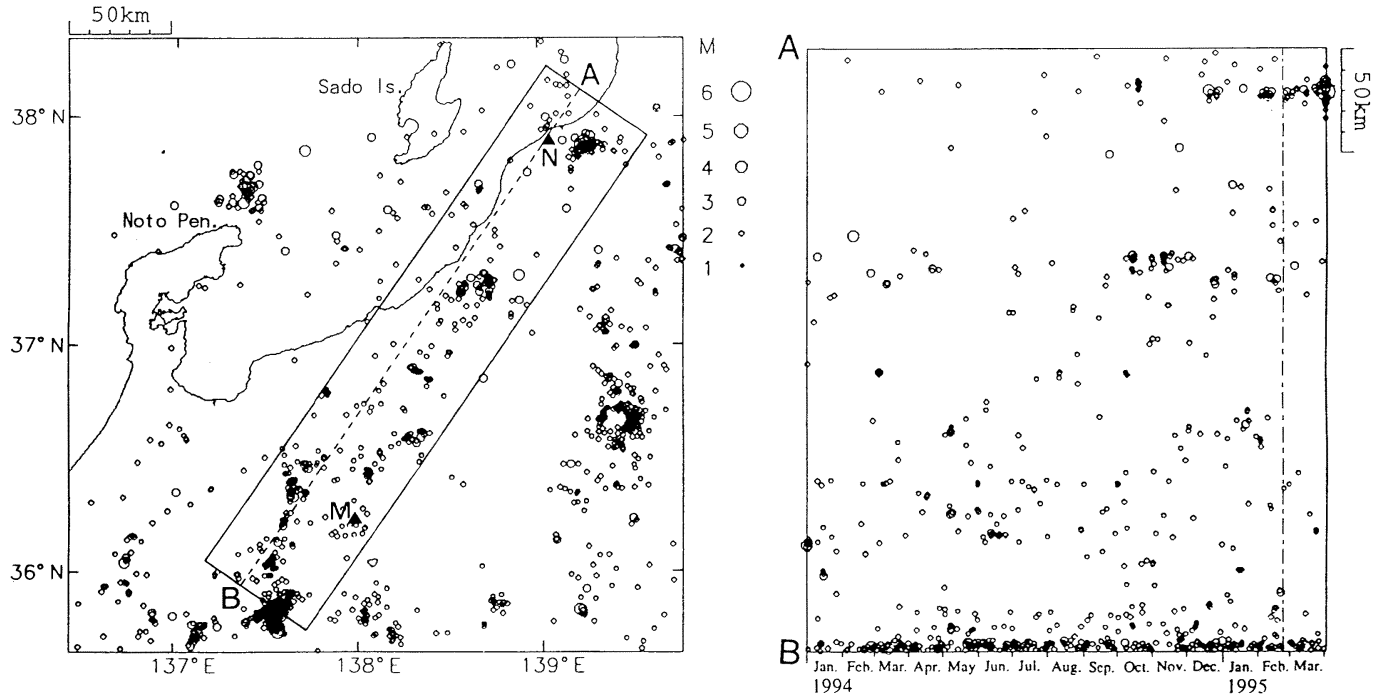

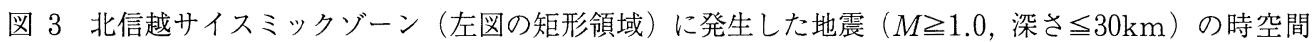
分布。期間は1994.1.1-1995.4.1.

$\mathrm{N}:$ 新潟, $\mathrm{M}$ : 松本.

Fig. 3 Space-time disribution of earthquakes with $M \geqq 1.0$, depth $30 \mathrm{~km}$, occurred in the Hokushin-etsu seismic zone in the period Jan. 1, 1994-Apr. 1, 1995.

$\mathrm{N}$ and $\mathrm{M}$ indicate Niigata city and Matsumoto city, respectively.

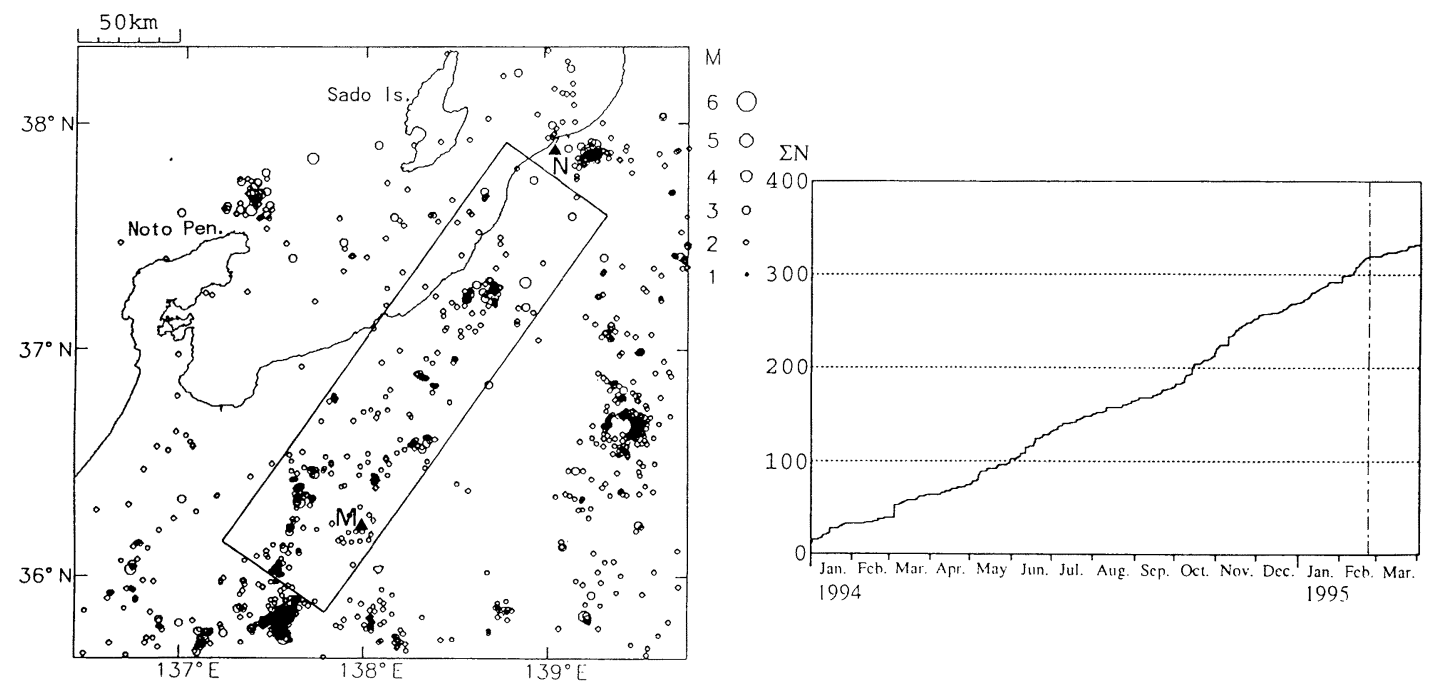

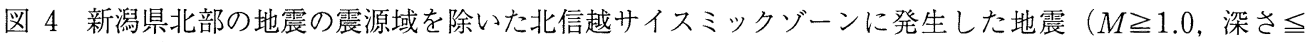
$30 \mathrm{~km}$ ）の積算.

$\mathrm{N}$ : 新潟, $\mathrm{M}$ : 松本.

Fig. 4 Cumulative number of earthquakes in the Hokushin-etsu seismic zone except the focal region of the northern Niigata earthquake.

$\mathrm{N}$ and $\mathrm{M}$ indicate Niigata city and Matsumoto city, respectively. 

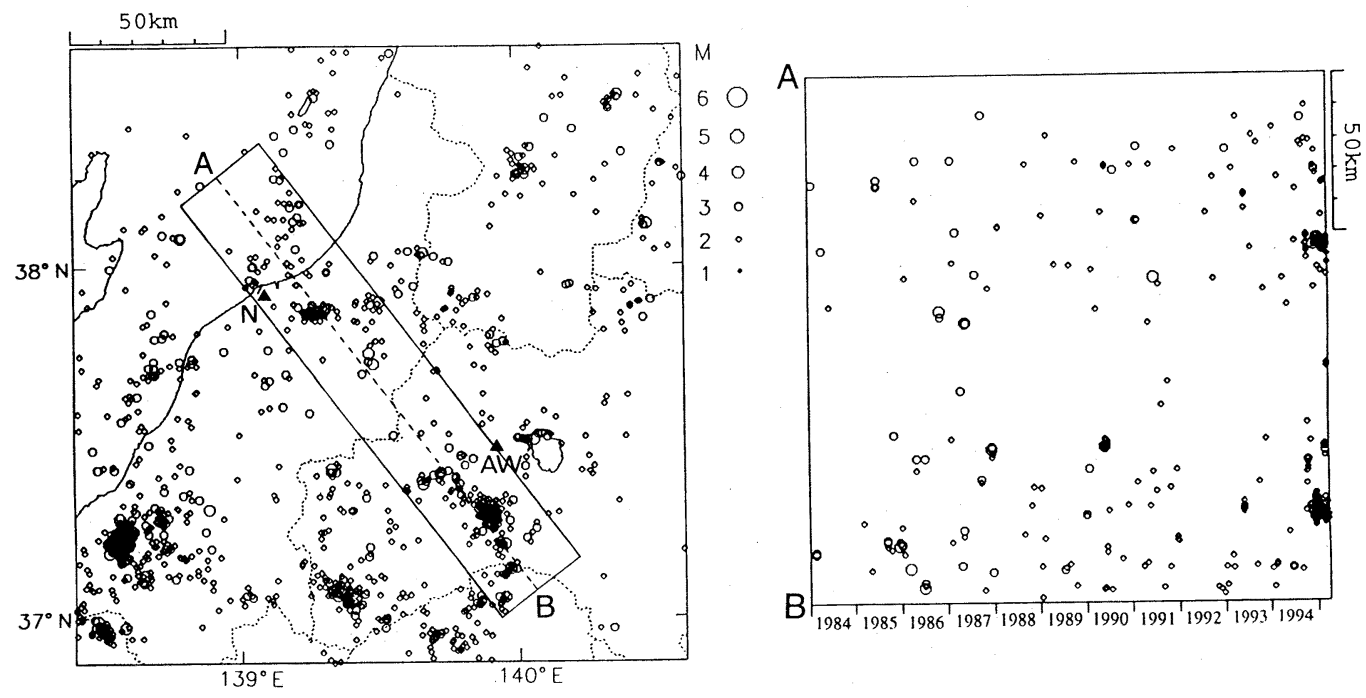

図 5 新潟県北部の地震の震源域と福島県西部の活動域を結ぶゾーン（左図の矩形領域）に発生した地震 $(M \geqq 2.0$, 深さ $\leqq 30 \mathrm{~km})$ の時空間分布. 期間は1984. 1. 1-1995. 3. 31.

$\mathrm{N}:$ 新潟, $\mathrm{AW}$ : 会津若松.

Fig. 5 Space-time disribution of earthquakes with $M \geqq 2.0$, depth $\leqq 30 \mathrm{~km}$, occurred during the period Jan. 1, 1984-Mar. 1, 1995 in the zone connecting the focal region of the northern Niigata earthquake and the western part of Fukushima prefecture. $\mathrm{N}$ and $\mathrm{AW}$ indicate Niigata city and Aizu-Wakamatsu city, respectively.
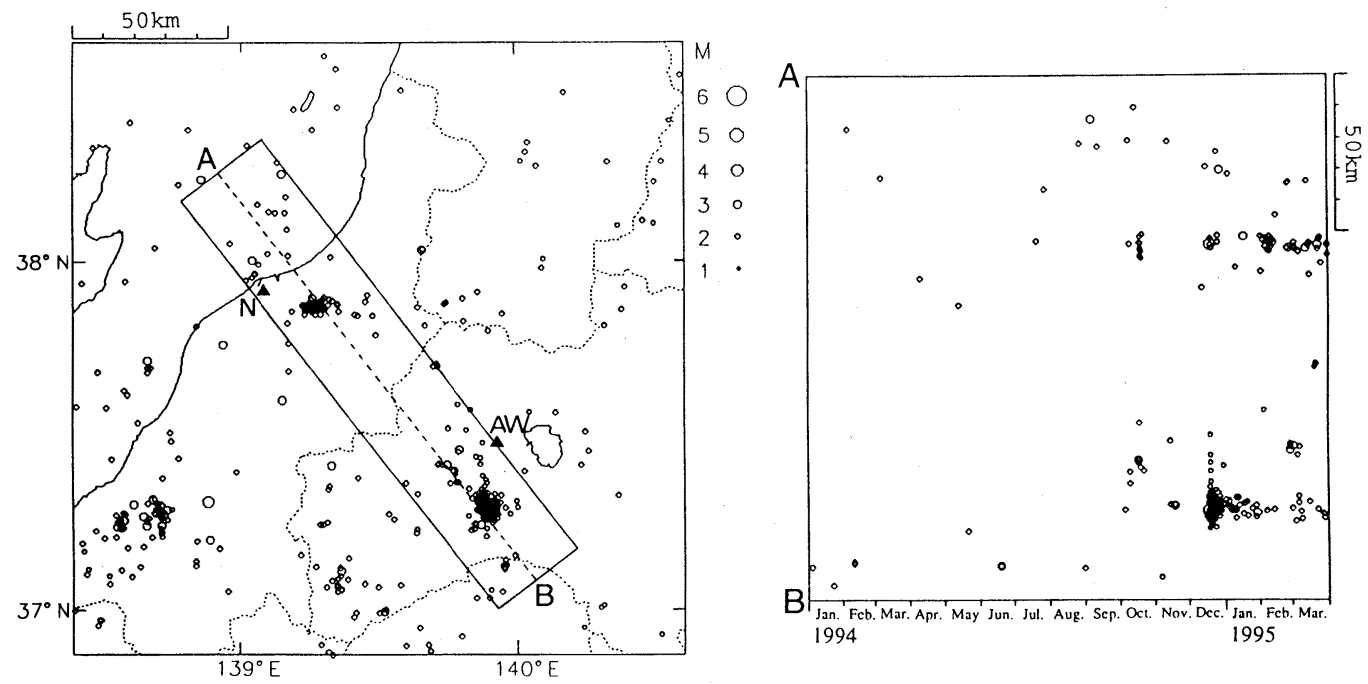

図 6 新潟県北部の地震の震源域と福島県西部の活動域を結ぶゾーンに発生した地震（ $M \geqq 1.0$, 深さミ $30 \mathrm{~km}$ ）の時空間分布. 期間は1994. 1.1-1995. 3. 31.

$\mathrm{N}$ : 新潟, $\mathrm{AW}$ : 会津若松.

Fig. 6 Space-time disribution of earthquakes with $M \geqq 1.0$, depth $\leqq 30 \mathrm{~km}$, occurred during the period Jan. 1, 1994-Mar. 31, 1995 in the zone connecting the focal region of the northern Niigata earthquake and the western part of Fukushima prefecture. 

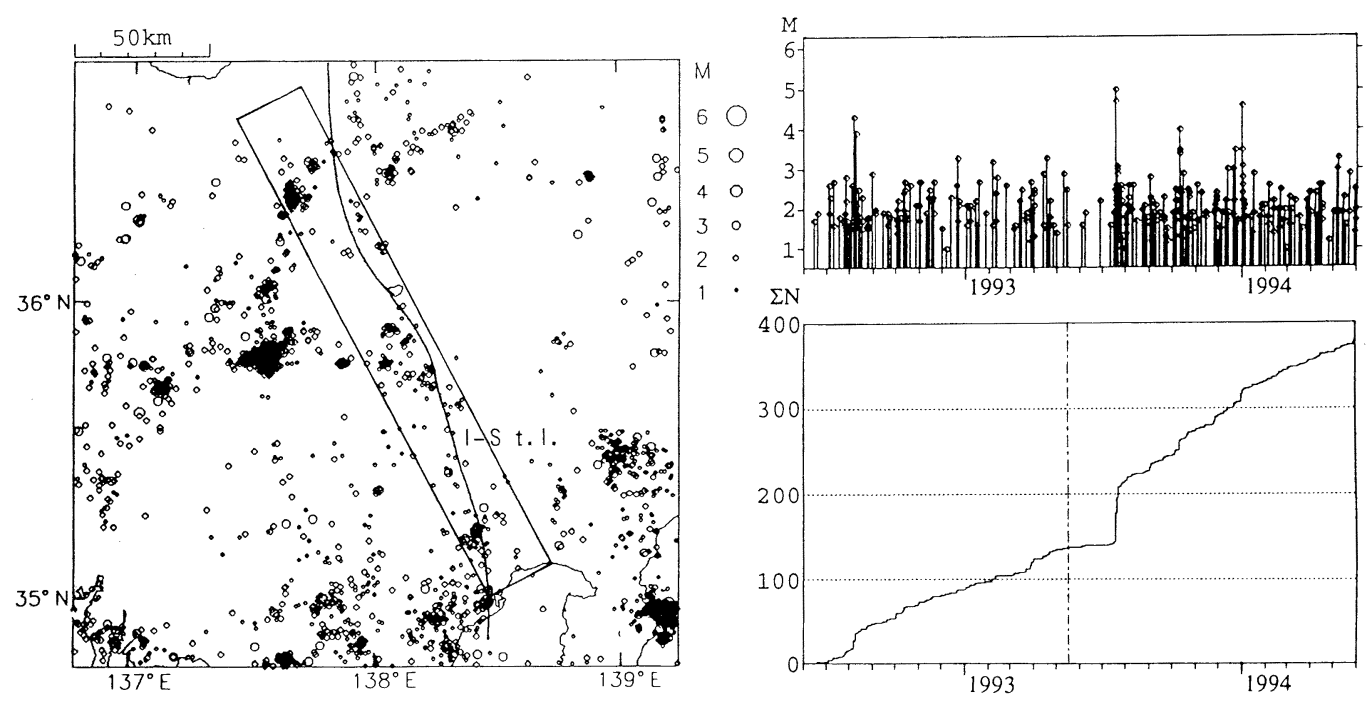

図 7 糸魚川-静岡構造線沿いに, 飛騨と駿河湾北岸を結ぶゾーンに発生した地震（ $M \geqq 1.0$, 深さミ30 $\mathrm{km}$ ）の M-T 図（右上）と積算（右下）。期間は1992.6. 1-1994. 5. 31.

I-S t. 1. は糸魚川-静岡構造線を示す.

Fig. 7 Magnitude-time diagram and cumulative number of earthquakes with $M \geqq 1.0$, depth $\leqq 30 \mathrm{~km}$, occurred during the period Jun. 1, 1992-May 31, 1994 in the zone connecting the Hida mountain area and the northern coast of Suruga Bay along Itoigawa-Shizuoka tectonic line.

I-S t. 1. indicates Itoigawa-Shizuoka tectonic line.

線沿いのゾーンに発生した地震の時空間分布と積 算を示したものである。これらの図から，1993年 7 月の活動が始まる直前の 2 カ月間ほど, このゾー ンの地震活動が低下した様子がはっきりと見てと れる。糸魚川-静岡構造線は東北日本と西南日本 の地質境界にあたるフォッサマグナ西縁を画する 第 1 級の構造線で, 諏訪湖から松本にかけてはそ れに沿ってA級の活断層も存在する（活断層研究 会, 1991)。この典型的な内陸ブロック構造境界 である糸魚川-静岡構造線に沿って，その近辺で 発生した顕著な群発的活動の直前に小地震の発生 の低下が見られたということは，たいへん示唆に 富む興味深い事実であると考える。

\section{（d）1995年駿河湾北部の地震（M5.1）}

1995年 4 月18日，駿河湾北部でM5.1の地震が発 生した（改訂 $M$ 值は 4.5)。図 8 は1994年 1 月か ら1995年 4 月までの期間における，駿河トラフ沿 い及びその北側延長領域の地震の時空間分布であ る。この時空間分布図から, 同ゾーンの活動は 2
月初め頃から極めて静かであった様子が見てとれ る。

駿河トラフはフィリピン海プレートがユーラシ アプレートの下に沈み込む境界にあたり，その北 側の陸上部にはA級活断層の富士川断層系が続い ている。しかし, 駿河湾北部の地震のメカニズム 解から求まる主圧力軸は北東一南西方向で, フィ リピン海プレートの沈み込み方向とはほぼ直交す る(気象庁地震予知情報課, 1995b)。防災科学技 術研究所 (1995) は, この地域の震源分布と上の メカニズム解とから, 駿河湾北部の地震はフィリ ピン海プレート内に震源を持つ, プレートを切る 地震であったと推定している。その意味で, この 静穏化は内陸地震に伴ったものとはいえないかも しれないが，やや顕著な地震の前にその震源域付 近を通るテクトニックゾーンに沿って静穏化現象 が生じた一つの例にあげることはできよう。

（e）1993年能登半島沖地震 $(M 6.6)$

図 9 は1993年能登半島沖地震の震源域とその周 

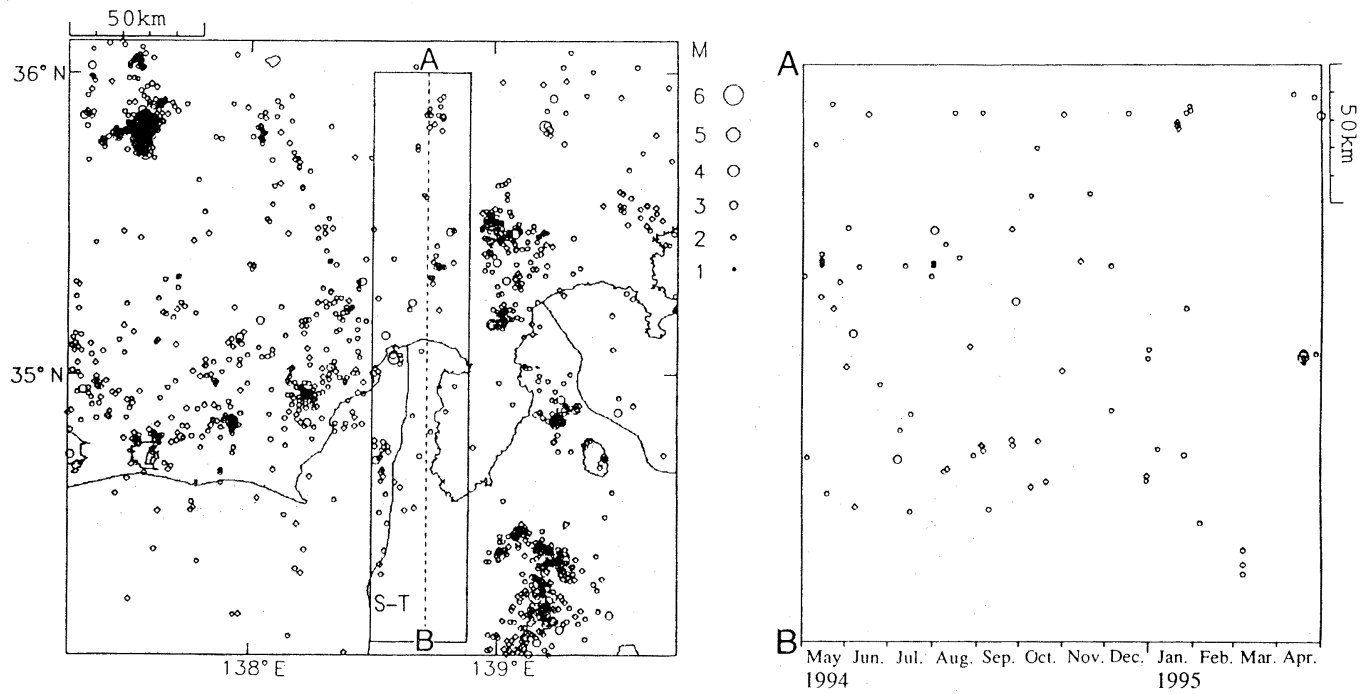

図 8 駿河トラフ沿い, 及びそれを北側に延長した富士川断層系沿いに発生した地震（ $M \geqq 1.0$, 深さミ40 $\mathrm{km}$ ）の時空間分布. 期間は1994. 1. 1-1995. 4. 30.

S-T は駿河トラフを示す。

Fig. 8 Space-time disribution of earthquakes with $M \geqq 1.0$, depth $\leqq 40 \mathrm{~km}$, occurred during the period Jan. 1, 1994-Apr. 30, 1995 in the zone along the Suruga trough and its extended region to the north.

$\mathrm{S}-\mathrm{T}$ indicates Suruga trough.

辺の地震の発生時系列を示したものである。能登 半島沖地震は 2 月 7 日に発生したが, 前年の 12 月 半ば頃から周辺の広い範囲で地震活動が顕著に静 穏化したことがこの図 9 から明らかである。能登 半島沖地震のメカニズム解は北西-南東方向に主 圧力軸方向を持つ逆断層であり, 余震の多くが深 さ 10-30km に分布している(気象庁地震予知情 報課，1993）ことから地款内地震であったと推定 される。しかし，この震源域近傍の海底に該当す る活断層は見つかっていない。また, 能登半島周 辺の地質構造も明らかではない。図 9 に見られる ように, 能登半島沖地震の前の地震活動の静穏化 は特定のゾーンに沿ってというより震源域周辺一 帯で生じていることから, テクトニックな応力区 という観点から見た場合には，この区域全体が一 つのブロックを構成していると考えてもよいと思 われる。

能登半島沖地震の震源のすぐ近くで1992年12月 10日にM3.0と M 3.2 の地震が発生している。震 源域近傍は近年ほとんど地震が起きていなかった
ところであるので，これらの地震は前震であった と考えてよいだろう。興味深いことに, 震源周辺 の地震活動の時空間分布を見ると, 次第に能登半 島沖地震の震源に近いところで地震が起き始めて いた傾向が認められる（図10）。こうした特徵は 1963年越前岬沖地震 $(M 6.9)$ の場合にも見られた。

（f）長野県西部の群発地震活動（ $M 5.1$ 及び $M$ 5.3)

1984年長野県西部地震（M6.8）の震源域付近 では，直後の余震活動が納まった後も群発的活動 がほとんど途切れることなく続いている。この間， 1993年 4 月23日には $M 5.1$ の地震が発生し，また 1994年になってそれまでの活動域の約 $10 \mathrm{~km}$ 南で 新たな活動が始まり，その中で1995年 3 月 17 日に $M 5.3$ の地震が発生した（気象庁地震予知情報課, 1995c)。

図11はこの南側の活動域について，1994年 1 月 以降の地震の発生時系列と積算を示したものであ る。これらの図から，1995年 3 月 17 日の M5.3の 地震（活動域の南端で発生）の前の約 2 力月間, 

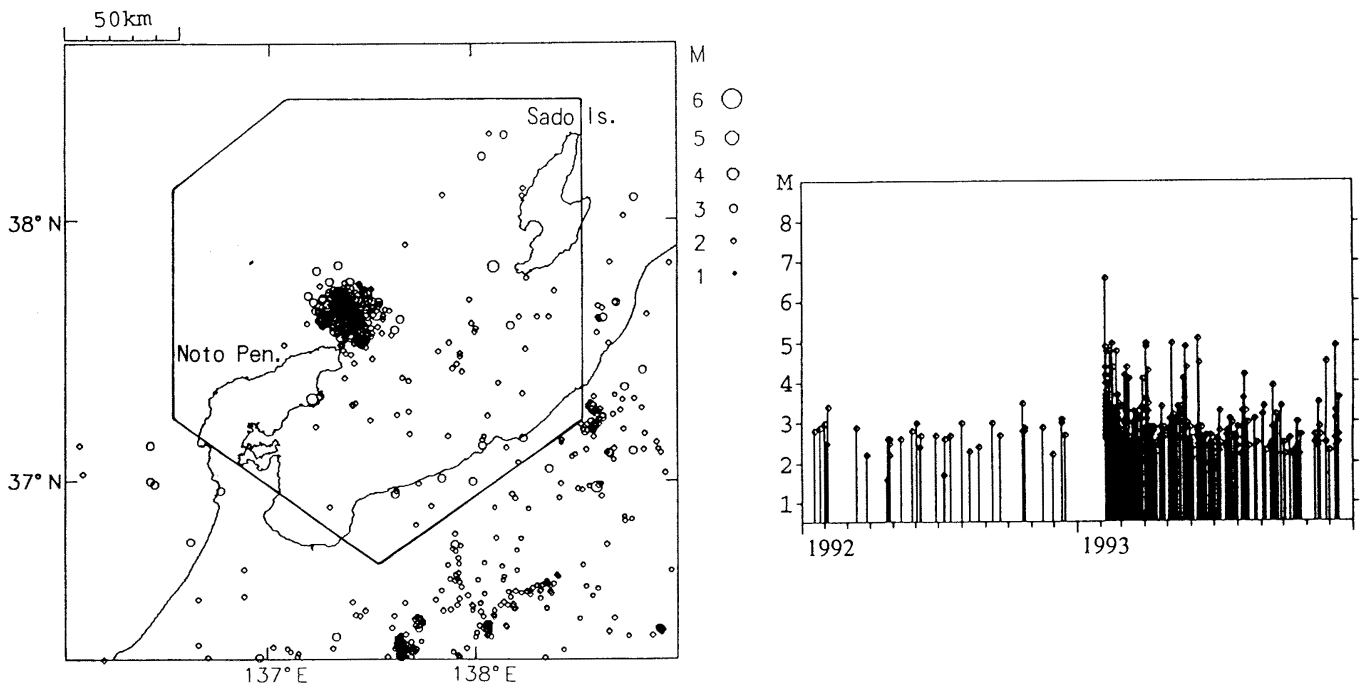

図 9 1993年能登半島沖地震の震源域とその周辺に発生した地震 $(M \geqq 1.0$, 深さミ40km) の $\mathrm{M}-\mathrm{T}$ 図. 期間は1992. 1.1-1993. 12. 31.

Fig. 9 Magnitude-time diagram of earthquakes with $M \geqq 1.0$, depth $\leqq 40 \mathrm{~km}$, occurred during the period Jan. 1, 1992-Dec. 31, 1993 in the focal region of the 1993 off-Noto Peninsula earthquake and its surrounding area.
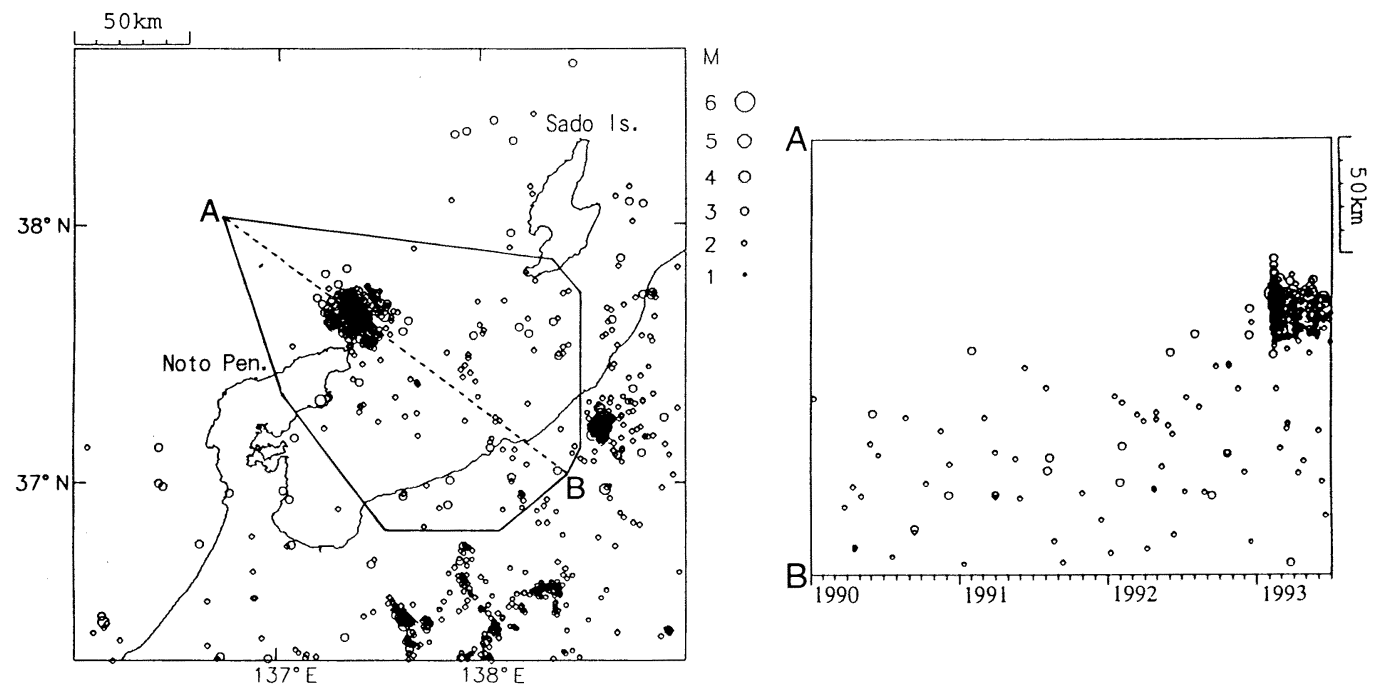

図10 1993年能登半島沖地震の震源域とその周辺に発生した地震 $(M \geqq 1.0$, 深さ $\leqq 40 \mathrm{~km})$ の時空間分布. 期間は1990. 1. 1-1993.6. 30 。

Fig. 10 Space-time disribution of earthquakes with $M \geqq 1.0$, depth $\leqq 40 \mathrm{~km}$, occurred during the period Jan. 1, 1990-Jun. 30, 1993 in the focal region of the 1993 off-Noto Peninsula earthquake and its surrounding area. 

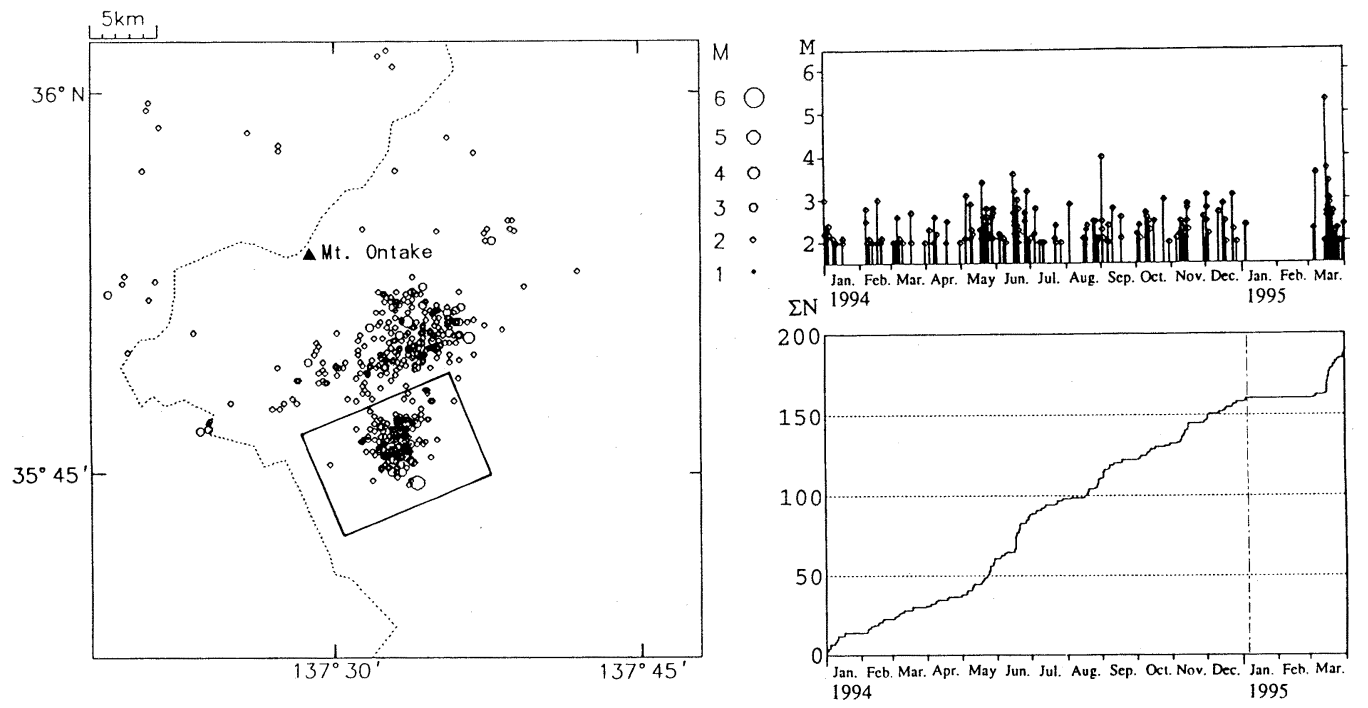

図11 長野県西部の群発活動域に発生した地震（ $M \geqq 2.0$, 深さ $\leqq 30 \mathrm{~km})$ の $\mathrm{M}-\mathrm{T}$ 図（右上）と積算（右 下)。期間は1994. 1.1-1995. 3. 31.

Fig. 11 Magnitude-time diagram and cumulative number of earthquakes in the seismically active region of the western Nagano prefecture during the period Jan. 1, 1994-Mar. 31, 1995.

地震活動が明膫に静穏化したことがわかる。しか し, 北側の活動域では，この間，特に静穏化した 様子は見られない。

このように，群発活動に関してもその中で発生 する顕著な地震の前に静穏化現象がしばしば現わ れる。しかしその場合には静穏化は群発活動に限 られ，周辺の広い範囲に及ぶということはないよ うである。これは群発的活動が広域のテクトニッ クな応力場の作用の下で生じるというょり，例え ばマグマの活動のような局所的な要因によって起 きることが多いためと考えられる。なお， 3 月 7 日の $M 3.6$ の地震 (図11の $\mathrm{M}-\mathrm{T}$ 図を参照) は 3 月17日の $M 5.3$ 地震のごく近くで発生している。 前述したように，1993年 4 月 23 日に長野県西部 地震以後続いていた活動域の中で $M 5.1$ の地震が 発生した。この地震の前, 地震回数は急激な増加 傾向を見せ, 名古屋大学理学部（1993）によって 地震の日回数の逆数を基にした発生時期の予測も なされている。しかし，図12の積算に見るよう に, $M 5.1$ の地震の発生の直前 2 日間ほどは, むし ろ活動が低下していた。この静穏化はこれまでに
見た例と比べて期間が非常に短いが，1993年春の 長野県西部の活動は 3 月に入って急激に活発化し たものであり，いわば背景となっていた活動自体 が短期間のものであった。そのために静穞化の期 間も相対的に短くなったということが考えられる。

上述の長野県西部の群発活動についての二つの 例は，静穏化域の範囲やその継続期間が，背景の 活動を生じさせている応力場の空間的スケールや， またその変化の時間的スケールによって規定され ていることを示しているように思われる。

\section{III. 議 論}

本論文で紹介した静榣化現象は本震の規模から 考えるとその範囲が広く, 地震発生との因果的関 連性を, 例えば震源核形成モデル (Ohnaka, 1992 ; Shibazaki and Matsu'ura, 1995) 等によって説 明することは難しい。しかし, 気象庁の微小地震 観測網が充実した近年に内陸で発生したやや規模 の大きな地震の前に，ほぼ共通してそうした広域 静穏化現象が観測されているということは，それ らが単なる偶然のものではなくて地震発生過程の 


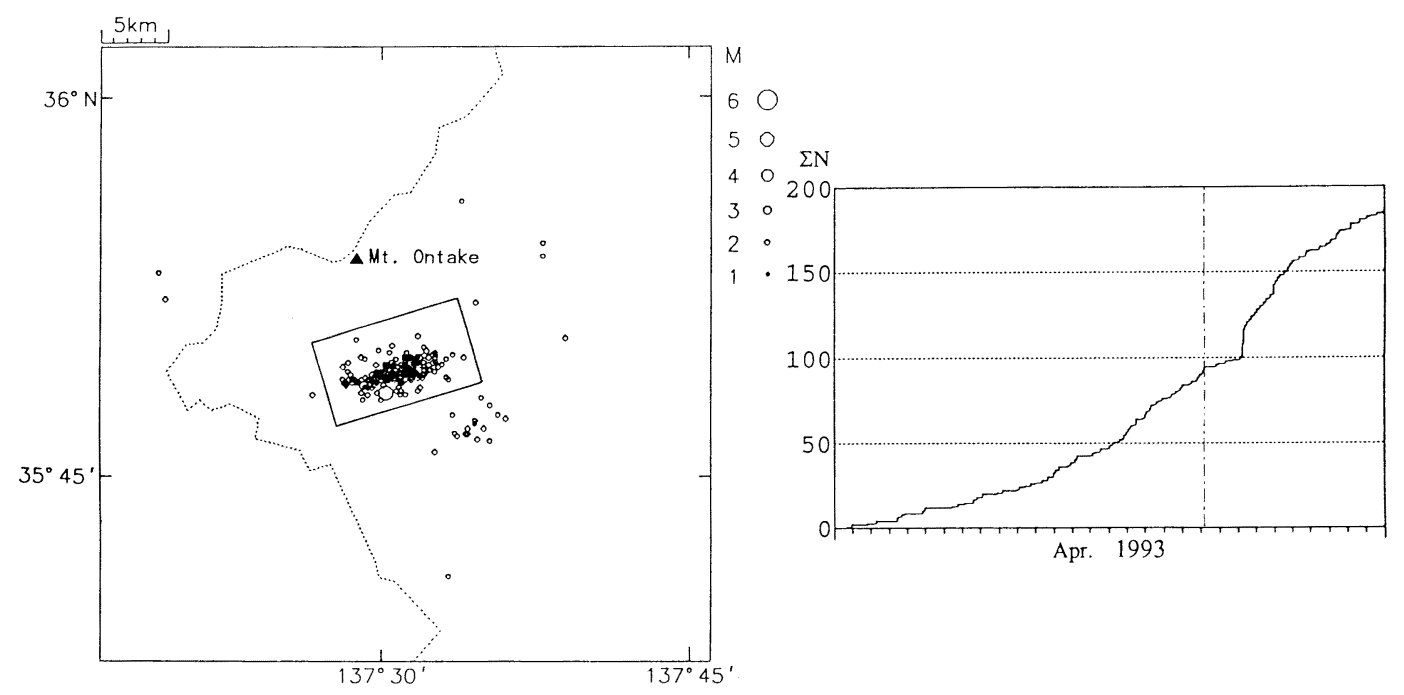

図12 長野県西部の群発活動域に発生した地震（ $M \geqq 1.0$, 深さミ30km）の積算. 期間は1993. 4. 1-1993. 4. 30 .

Fig. 12 Cumulative number of earthquakes in the seismically active region of the western Nagano prefecture during the period Apr. 1, 1993-Apr. 30, 1993.

中で何らかの意味を持つ現象であることを示して いる。著者らがこの現象を重要と考えるのは, そ れが, 震源域よりもずっと広い領域が地震発生プ ロセスに関わっていることを示すとともに，断層 運動の開始, 成長が破壊開始点近傍の条件だけに よって決まっているのではないことをも示唆する からである。

この問題について, ここでこれ以上詳述する準 備はできていないが，一つだけ注意しておきたい ことは, 静穏化が地款のテクトニックな, あるい は力学的な構造と密接に関係しているらしいとい うことである。このことは内陸における応力の蓄 積や解放のプロセスに, 地殼のブロック的構造が 大きな役割を果たしていることを示すものである。 著者らは, このプロセスを明らかにすることは内 陸地震の発生機構の解明にとって決定的に重要な 意義を持つと考えている。

ところで，震源から遠く離れたところで前兆現 象が観測されたという報告をしばしば目や耳にす る。もし, 前兆現象というものが震源からの距離 に依存した現われ方をし，近い観測点ほど例えば 振幅が大きくなければならないとしたら，そうし
た遠方でのみ観測された “前兆現象”というのは 基準を満たさないノイズということになってしま う（Wyss，1991）。しかし，本論文で紹介した静 穏化現象が実際に広域における応力場の変化を現 わしているのたとしたら，震源から見て特定の方 向で, 直前に, そして遠方で前兆現象が観測され るということも可能性としてありえないことでは ない。前兆現象の評価や解釈をそういった観点か ら試みてみることも, 地震発生メカニズムの解明 への手がかりにつながるかもしれない。

このような基本的な問題とは別に, 実際的な, 例えば地震予知の面でも, 本論文で紹介した静穏 化現象は大きな意義を内包している。それは，こ の現象が広域で生じ, かつ直前に現われるという ことから，その検出が比較的容易であるとともに， 地震予知の 3 要素, 場所 · 大きさ・時間のうち, もっとも困難と見られている発生時の短期的な予 測にとって有力な手がかりとなる可能性を持って いるからである。本論文で示した例では，最後の 長野県西部の群発活動の中の地震を除いて, 静穏 化期間はすべて $1 \sim 2$ 力月となっている。冒頭で 述べた兵庫県南部地震の場合も約 1 カ月であった 
(吉田, 1995 ; 京都大学防災研究所, 1995)。そう した点で, 今後, この現象の短期的地震予知への 実践的な活用を図っていくことは大いに意義があ ると思われる。また, 地震発生メカニズムの研究 という観点からは, 発現の時空間パターンの地域 性やテクトニクスとの関連性を明らかにしていく 努力が重要となるであろう。

\section{文 献}

防災科学技術研究所 (1995)：1995年 4 月18日駿河湾北 部の地震 (M5.1). 地震予知連絡会会報, 54, 384-387. 藤田和夫 (1983) : 日本の山地形成論. 蒼樹書房, 466p. 石川有三 (1990): 日本列島内陸部の地震空白域。月刊 地球, 12, 355-361.

活断層研究会 (1991) : 新編 日本の活断層. 東京大学出 版会, $437 \mathrm{p}$.

気象庁地震予知情報課 (1993) : 能登半島沖の地震 (1993 年 2 月 7 日, M6.6). 地震予知連絡会会報, $50,478-$ 485.

気象庁地震予知情報課 (1995a) : 新潟県北部の地震 (1995年 4 月 1 日，M6.0). 地震予知連絡会会報， 54， 111-117.

気象庁地震予知情報課 (1995b) : 駿河湾北部の地震 （1995年 4 月18日，M5.1）。地震予知連絡会会報， 54， 378-383.

気象庁地震予知情報課 (1995c) : 関東・中部地方とその 周辺の地震活動（1994年11月～1995年 4 月）. 地震予 知連絡会会報, 54, 210-218.

京都大学防災研究所 (1995): 第116回地震予知連絡会資 料.

Mogi, K. (1988): The mechanism of the occurrence of the Matsushiro earthquake swarm in central Japan and its relation to the 1964 Niigata earthquake. Tectonophysics, 159, 109119.

名古屋大学理学部 (1993) : 長野県西部の地震（1993年4 月23日・M5.1). 地震予知連絡会会報, 50, 146-151.
大森房吉（1910）: 本邦大地震概説。震災予防調査会報 告, $68,1-180$.

Ohnaka, M. (1992) : Earthquake source nucleation: A physical model for short-term precursor. Tectonophysics, 211, 149-178.

大塚弥之助（1942）：活動している褶曲構造. 地震，14, 46-63.

Shibazaki, B. and Matsu'ura, M. (1995) : Foresho cks and pre-events associated with the nucleation of large earthquake. Geophys. Res. Lett., 22, 1305-1308.

田口陽介・吉田明夫（1996）: 福島県西部と新潟県北部 の地震活動の相関. 験震時報, 印刷中.

東北大学理学部 (1995)：1995年 4 月 1 日に新潟県北部 で発生した M6.0の地震について. 地震予知連絡会会 報, 54, 106-110.

Wyss, M. (1991) : Guidelines for submission of earthquake precursor candidate. In Wyss, M. ed.: Evaluation of proposed earthquake precursors. Amer. Geophys. Union, Washington, D. C., 94p.

Yoshida, A. (1987): Characteristic patterns in the space-time distribution of large shallow earthquakes in the Japanese islands. Tectonophysics, 136, 283-297.

Yoshida, A. (1989): Characteristic space-time patterns in seismic activity in the northwest Chubu district of Honshu island, Japan, and the 1984 Nagano-ken Seibu earthquake. Tectonophysics, 167, 93-102.

吉田明夫（1995）：丹波と丹波西方域及び和歌山付近の 地震活動の相関と兵庫県南部地震. 地学雑誌, 104, 801-808.

Yoshida, A., Maeda, K. and Takayama, H. (1994): Spatiotemporal patterns of clustered and non-clustered seismic activity in the Shin-etsu and Tokai regions, central Japan. Geophys. Res. Lett., 21, 915-918.

(1995年11月 6 日受付，1995年12月18日受理） 